\title{
Effect of Corn Silage Hybrid and Metabolizable Protein Supply on Nitrogen Metabolism of Lactating Dairy Cows ${ }^{1}$
}

\author{
W. P. Weiss ${ }^{2}$ and D. J. Wyatt \\ Department of Animal Sciences, Ohio Agricultural Research and Development Center, The Ohio State University, Wooster 44691
}

\section{ABSTRACT}

This experiment was conducted to determine the effects of corn silage hybrid and supply of metabolizable protein (MP) on manure excretion and N metabolism by lactating dairy cows. Eight Holstein cows in midlactation (replicated $4 \times 4$ Latin square with 21 -d periods) were fed 1 of 4 treatments, arranged factorially. Diets contained 55\% corn silage made from a dual-purpose hybrid or a brown midrib (BMR) hybrid, and $45 \%$ concentrate that contained either a low or high concentration of rumen undegradable protein (altered by the addition of fish meal and treated soybean meal). Crude protein averaged 14.0 and $17.5 \%$ and supply of MP averaged 2,360 and 2,990 g/d for the low and high MP treatments (not affected by hybrid). Increasing supply of MP greatly increased urine output and tended to increase total manure output, whereas diets with BMR silage tended to reduce manure output. Increased MP supply increased daily excretion of manure $\mathrm{N}$ by $25 \%$ ( $465 \mathrm{vs} .374 \mathrm{~g} / \mathrm{d}$ ), fecal $\mathrm{N}$ by $27 \mathrm{~g}$, and urinary $\mathrm{N}$ by $64 \mathrm{~g}$. When the effect of $\mathrm{N}$ intake was removed, cows fed BMR silage excreted about $15 \mathrm{~g} / \mathrm{d}$ less $\mathrm{N}$ via manure than cows fed the other silage. Rumen ammonia, volatile fatty acid concentrations, and $\mathrm{pH}$ were not affected by treatment. Dry matter intake (overall mean $=24.9 \mathrm{~kg} / \mathrm{d}$ ) tended to be increased with increased MP but was not affected by hybrid. Milk production for cows fed BMR was higher than for cows fed the dual-purpose hybrid (36.9 vs. $35.3 \mathrm{~kg} / \mathrm{d}$ ), but because of changes in fat concentration, yield of energy-corrected milk was not affected by treatment. The only interaction observed was increased yield of milk protein when BMR silage was combined with increased supply of MP.

Key words: manure, nitrogen, corn silage, digestibility

\footnotetext{
Received November 4, 2005.

Accepted November 28, 2005.

${ }^{1}$ Salaries and research support provided by state and federal funds appropriated to the Ohio Agricultural Research and Development Center, The Ohio State University. Additional funds provided by Dow AgroSciences, LLC, Indianapolis, IN. Manuscript 26-05AS.

${ }^{2}$ Corresponding author: weiss.6@osu.edu
}

\section{INTRODUCTION}

Manure is an inevitable by-product of the production of milk and meat. Excessive excretion of manure and manure nutrients represent inefficiencies that increase feed costs, increase the costs associated with storing and handling manure, and increase the environmental impact of dairy farming. With increased societal concerns and regulations (EPA, 2003) regarding animal agriculture, we must develop management and nutritional practices that reduce excretion of manure and manure nutrients.

Identifying factors that affect the gross efficiency of $\mathrm{N}$ use by dairy cows ( $\mathrm{N}$ output in milk divided by $\mathrm{N}$ intake) continues to be a major research emphasis in several areas of the world because efficiency is relatively low and because of the potential impact of manure $\mathrm{N}$ on water and air quality. From surveys of commercial dairy farms in the United States, the average gross efficiency of $\mathrm{N}$ use by lactating cows is $<30 \%$ (Jonker et al., 2002; Spears et al., 2003). Feeding diets that are formulated to provide adequate, but not excessive, amounts of RDP and RUP has been shown to have a major impact on $\mathrm{N}$ efficiency and excretion of manure N (St-Pierre and Thraen, 1999; Jonker et al., 2002). Limited data suggest that corn silage made from brown midrib (BMR) hybrids may reduce excretion of $\mathrm{N}$, especially via urine (Greenfield et al., 2001; Tine et al., 2001). Cows fed BMR silage usually have higher DMI and often have greater milk production than cows fed silage made from conventional hybrids (Oba and Allen, 1999; Tine et al., 2001).

We hypothesized that the increased consumption of rumen fermentable OM by cows fed BMR silage (Oba and Allen, 2000b; Greenfield et al., 2001) allowed greater conversion of RDP into microbial protein thereby reducing ammonia absorption through the rumen and reducing urinary $\mathrm{N}$ excretion. Because cows fed BMR silage also have higher intake of $\mathrm{NE}_{\mathrm{L}}$ and thus more energy available for milk production (Tine et al., 2001), we postulated that when cows were fed BMR silage and supplemented with RUP, yield of milk protein would increase to a greater extent than for cows fed conventional hybrids. The primary objective of this experiment was to determine whether feeding 
Table 1. Nutrient composition (DM basis) of corn silage made from a brown midrib (BMR) or dual-purpose (DP) hybrid ${ }^{1}$

\begin{tabular}{lcllll}
\hline & \multicolumn{2}{c}{ BMR } & & \multicolumn{2}{c}{ DP } \\
\cline { 2 - 3 } \cline { 5 - 6 } & Mean & SD $^{2}$ & & Mean & SD $^{2}$ \\
\hline DM, \% & 37.4 & 2.1 & & 37.5 & 1.4 \\
Gross energy, Mcal/kg & 4.20 & 0.038 & & 4.26 & 0.040 \\
Ash, \% & 4.17 & 0.33 & & 3.82 & 0.23 \\
CP, \% & 8.25 & 0.38 & & 8.06 & 0.40 \\
NDF, \% & 39.8 & 1.71 & & 40.3 & 2.92 \\
ISNDFD, \% of NDF & 64.4 & 2.72 & & 55.5 & 1.99 \\
IVNDFD, \% of NDF & 65.2 & 4.90 & & 58.3 & 5.72 \\
Lignin, \% & 1.00 & 0.078 & & 1.96 & 0.11 \\
Starch, \% & 31.5 & 1.23 & & 31.5 & 2.50 \\
Long-chain fatty acids, \% & 1.7 & - & & 1.9 & - \\
pH & 3.83 & 0.089 & & 3.72 & 0.045 \\
Ca, \% & 0.22 & 0.008 & & 0.16 & 0.011 \\
P, \% & 0.19 & 0.007 & & 0.20 & 0.014 \\
K, \% & 0.89 & 0.050 & & 0.93 & 0.010 \\
\hline
\end{tabular}

${ }^{1}$ ISNDFD and IVNDFD $=$ in situ and in vitro NDF digestibility, respectively. Samples for both analyses were incubated for $48 \mathrm{~h}$.

${ }^{2}$ Standard deviation calculated from 4 samples of each silage taken during each total collection period (long-chain fatty acids were assayed from a single composite of those 4 samples). Samples were taken for 4 consecutive days each period and composited by period.

$\mathrm{BMR}$ silage reduced excretion of $\mathrm{N}$ via manure when dairy cows were fed excess CP (i.e., increased the efficiency of converting dietary $\mathrm{N}$ into milk $\mathrm{N}$ ).

\section{MATERIALS AND METHODS}

\section{Silages}

A dual-purpose (DP) corn hybrid (Mycogen 7511FQ, Dow AgroSciences, LLC, Indianapolis, IN) and a BMR hybrid (Mycogen F697 BMR, Dow AgroSciences) were planted on May 19, 2003, in 2 fields (each approximately $3.6 \mathrm{ha}$ ) located within $1 \mathrm{~km}$ of each other at the Ohio Agricultural Research and Development Center (Wooster). Seeding rate was 73,800 and 70,400 seed/ha for the DP and BMR, respectively. All other agronomic practices were identical for each field. Silages were harvested using the same forage chopper $(0.95-\mathrm{cm}$ theoretical length of cut without kernel processing) on October 13 (DP) and October 14 (BMR), 2003, and placed into 2 identical glass-lined steel silos (Harvestore, ESP Co., DeKalb, IL). The silages remained undisturbed for approximately 3 mo before the start of the feeding experiment.

\section{Diets and Cows}

Four different diets were formulated that contained DP or BMR corn silage and either 14.0 or $17.5 \% \mathrm{CP}$ (Tables 1 and 2). All diets were formulated to contain 10\% RDP (DM basis) as calculated using the NRC (2001) model with measured CP concentrations and
Table 2. Ingredient composition of diets (DM basis) with low and high CP concentrations ${ }^{1}$

\begin{tabular}{|c|c|c|}
\hline Ingredient & Low CP & High CP \\
\hline Corn silage $^{2}$ & 55.0 & 55.0 \\
\hline Corn grain, ground & 20.70 & 16.50 \\
\hline Soybean hulls & 8.48 & 6.47 \\
\hline Soybean meal, $44 \% \mathrm{CP}$ & 12.15 & 12.90 \\
\hline Lignosulfated soybean meal & 0.00 & 3.93 \\
\hline Fish meal, Menhaden & 0.00 & 2.52 \\
\hline Urea & 0.34 & 0.07 \\
\hline Animal-vegetable fat & 0.45 & 0.45 \\
\hline Limestone & 1.03 & 0.91 \\
\hline Dicalcium phosphate & 0.61 & 0.13 \\
\hline Dynamate $^{3}$ & 0.19 & 0.04 \\
\hline Magnesium oxide & 0 & 0.03 \\
\hline Sodium bicarbonate & 0.38 & 0.38 \\
\hline Trace mineral salt & 0.40 & 0.40 \\
\hline Vitamins/trace minerals ${ }^{4}$ & 0.27 & 0.27 \\
\hline
\end{tabular}

${ }^{1}$ The low and high diets contained 14.0 and $17.5 \% \mathrm{CP}$.

${ }^{2}$ The corn silage was either from a dual-purpose hybrid or a brown midrib hybrid.

${ }^{3}$ IMC Global, Lake Forest, IL.

${ }^{4}$ Premix contained (per kilogram): $115 \mathrm{mg}$ of Se (from sodium selenate), $3,410 \mathrm{mg}$ of $\mathrm{Cu}$ (from copper sulfate), 10,370 $\mathrm{mg}$ of zinc (from zinc sulfate), 1,525 kIU of vitamin A, $432 \mathrm{kIU}$ of vitamin D, and 8,200 IU of vitamin $\mathrm{E}$.

CP kinetic data from the NRC feed library (data for "normal corn silage" were used for both silages) and an assumed DMI of $23.5 \mathrm{~kg} / \mathrm{d}$. Diets with $14.0 \% \mathrm{CP}$ were estimated (NRC, 2001) to supply $85 \%$ of the MP needed to support $38 \mathrm{~kg} / \mathrm{d}$ of milk (average milk production of cows before the experiment began) and diets with $17.5 \% \mathrm{CP}$ were estimated to provide $115 \%$ of $\mathrm{MP}$ needed to support $38 \mathrm{~kg} / \mathrm{d}$ of milk. Diets met or exceeded NRC (2001) requirements for minerals and vitamins.

Eight Holstein cows in their second to fourth lactation and averaging 138 DIM $(\mathrm{SD}=33)$ at the start of the experiment were used. Four cows with rumen cannulas were assigned randomly to 1 of 4 treatment sequences within one $4 \times 4$ Latin square and 4 intact cows were assigned randomly to a treatment sequence in another orthogonal square. Periods were $21 \mathrm{~d}$ and both squares were conducted concurrently. Cows were housed in tie stalls, fed once daily, and milked twice daily with milk weights recorded electronically. Cows were weighed on $d 2$ and 21 of each period. Diets were fed as TMR for approximately 5\% feed refusal and the amounts of feed offered and refused were measured daily. On d 14 of each period, 6 preselected cows (the 4 cannulated cows plus 2 intact cows) were moved to stalls designed for total collection of urine and feces. We were limited to using 6 cows per period because only 6 metabolism stalls are available at our facility. Cows remained in those stalls for $4 \mathrm{~d}$, and were then moved back to the tie stalls for the remainder of the 
period. Procedures followed for total collection of feces and urine were described in Weiss and Wyatt (2000). Urine was collected into containers that contained adequate sulfuric acid to maintain urine $\mathrm{pH}<5$. On either d 18 or 19 of each period, rumen samples (via the cannula) were taken from the 4 cannulated cows immediately before feeding $(0 \mathrm{~h})$ and at $3,6,9$, and 12 $\mathrm{h}$ postfeeding.

\section{Samples and Analyses}

Silages were sampled weekly and analyzed for DM (24 $\mathrm{h}$ in $100^{\circ} \mathrm{C}$ oven) to adjust TMR for changes in silage moisture. Milk samples (a.m. and p.m.) were taken once each week and analyzed for fat and true protein with a B2000 Infrared Analyzer (Bentley Instruments, Chaska, MN) per approved methods (AOAC, 2000) and for MUN using a Skalar SAN Plus segmented flow analyzer (Skalar Inc., Norcross, GA) by Ohio DHI Cooperative, Inc. (Columbus, OH). During the digestion trials, feeds, orts, feces, urine, and milk were sampled daily, composited, and refrigerated $\left(4^{\circ} \mathrm{C}\right)$ during the collection period. Samples of urine, milk, and wet feces were analyzed for $\mathrm{N}$ using the Kjedahl procedure (AOAC, 2000) immediately following the last day of the collection period. Samples of feeds, orts, and feces were frozen, lyophilized, and then ground through a 1-mm screen (Wiley mill, Arthur H. Thomas, Philadelphia, PA). Ground samples were analyzed for $\mathrm{N}$ and ash (AOAC, 2000), energy (oxygen bomb calorimeter model 1281, Parr Instruments, Moline, IL), starch (Weiss and Wyatt, 2000), and NDF using amylase and sodium sulfite (Ankom Technology, 2003). Feeds were also analyzed for long-chain fatty acids (Weiss and Wyatt, 2000), minerals (inductively coupled plasma spectroscopy; AOAC, 2000), and sulfuric acid lignin (AOAC, 2000). Rumen fluid samples were analyzed for $\mathrm{pH}, \mathrm{VFA}$, and ammonia. The $\mathrm{pH}$ of the rumen fluid samples was measured immediately after sampling. The rumen fluid was then acidified in $10 \%$ phosphoric acid, centrifuged at $17,000 \times g$, filtered, and analyzed for VFA by GLC (Supelco, 1975). Ammonia was analyzed using a urea method except that urease was excluded and ammonium chloride was used for the standard curve rather than urea (Urea Nitrogen Procedure No. 640-A; Sigma Diagnostics, St. Louis, MO). Silage samples from all 4 digestion trials were composited, freeze-dried, and ground through a 2-mm screen (Wiley mill) and analyzed for 48-h in situ and in vitro NDF digestibility. In situ NDF digestibility was measured in duplicate in 2 cows ( 4 observations per silage) using Ankom (Fairport, NY) forage bags (approximately $3 \mathrm{~g}$ of sample/bag). The cows were fed a diet of approximately $35 \%$ corn silage (not those fed in this experiment), $25 \%$ alfalfa silage, and $45 \%$ corn grain-based concentrate). The in vitro NDF digestibility (IVNDFD) was measured at the University of Wisconsin-Madison/Extension, Soil and Forage Analysis Laboratory, Marshfield, WI.

\section{Statistical Analyses}

Milk production, milk composition, and DMI data from the last $2 \mathrm{wk}$ of each period were averaged within cow and analyzed using Proc MIXED (SAS Institute, 1999). Yield of milk components was calculated by multiplying the concentration of the component by the yield of milk on the days the sample was taken (not by multiplying average concentration by average milk yield over the entire 2 -wk period). The model included square (random, $1 \mathrm{df}$ ), cow within square (random, 6 df), period (random, $3 \mathrm{df}$ ), silage hybrid (fixed, $1 \mathrm{df}$ ), MP (fixed, 1 df), hybrid with MP interaction (fixed, 1 df), and error (18 df). Digestibility data were analyzed using Proc MIXED with cow (random, $5 \mathrm{df}$ ), period (random, $3 \mathrm{df}$ ), hybrid (fixed, $1 \mathrm{df}$ ), MP (fixed, $1 \mathrm{df}$ ), hybrid $\times$ MP (fixed, $1 \mathrm{df}$ ), and error (12 df). Rumen fluid data (only measured in the 4 cannulated cows) were analyzed with Proc MIXED with cow (random, 3 $\mathrm{df}$ ), period (random, $3 \mathrm{df}$ ), hybrid (fixed, $1 \mathrm{df}$ ), MP (fixed, $1 \mathrm{df}$ ), hybrid $\times$ MP (fixed, $1 \mathrm{df}$ ), error to test nonrepeated effects ( $6 \mathrm{df}$ ), time (fixed, repeated measure, $4 \mathrm{df}$ ), time $\times$ hybrid, time $\times \mathrm{MP}$, and time $\times$ hybrid $\times$ MP (all fixed, $4 \mathrm{df}$ each), and error for repeated measures (48 df). An additional statistical analysis was conducted to quantify the relationship between $\mathrm{N}$ intake and excretion of $\mathrm{N}$ in feces, urine, and manure. The model was the same as that used for digestibility data except that MP and MP interactions were not included in the model and were replaced with $\mathrm{N}$ intake as a continuous variable. The equal slopes hypothesis (between hybrids) was tested with a model that included hybrid as a fixed effect, $\mathrm{N}$ intake (continuous variable), and $\mathrm{N}$ intake $\times$ hybrid interaction. The equal intercept hypothesis was tested with a model that included hybrid as a main effect and $\mathrm{N}$ intake as a continuous variable.

\section{RESULTS AND DISCUSSION}

As expected, the BMR corn silage had higher in vitro and in situ NDF digestibility and a lower lignin concentration than the DP silage but all other measured components were similar between the 2 silages (Table 1 ). The concentration of estimated (NRC, 2001) RDP were similar among diets $(\sim 10 \%)$, but RUP concentration increased with increasing CP (4.3 and 7.0\% RUP for the low and high MP diets, respectively; Table 3). 
Table 3. Nutrient composition of diets and daily supply of $\mathrm{MP}^{1}$

\begin{tabular}{|c|c|c|c|c|}
\hline & \multicolumn{2}{|c|}{ BMR silage } & \multicolumn{2}{|c|}{ DP silage } \\
\hline & $\begin{array}{l}\text { Low } \\
\text { CP }\end{array}$ & $\begin{array}{l}\text { High } \\
\text { CP }\end{array}$ & $\begin{array}{l}\text { Low } \\
\text { CP }\end{array}$ & $\begin{array}{l}\text { High } \\
\text { CP }\end{array}$ \\
\hline $\mathrm{DM}, \%$ & 59.7 & 60.0 & 59.9 & 60.1 \\
\hline Gross energy, Mcal/kg & 4.18 & 4.23 & 4.21 & 4.27 \\
\hline $\mathrm{NE}_{\mathrm{L}}{ }^{2} \mathrm{Mcal} / \mathrm{kg}$ & 1.52 & 1.57 & 1.54 & 1.57 \\
\hline $\mathrm{CP}, \%$ & 14.4 & 17.2 & 14.2 & 17.1 \\
\hline $\mathrm{RDP},{ }^{2} \%$ & 9.9 & 10.1 & 9.9 & 10.1 \\
\hline RUP, ${ }^{2} \%$ & 4.5 & 7.1 & 4.3 & 7.0 \\
\hline $\mathrm{MP},{ }^{2} \mathrm{~g} / \mathrm{d}$ & 2,350 & 3,000 & 2,370 & 2,970 \\
\hline NDF, \% & 32.3 & 32.3 & 32.6 & 32.6 \\
\hline Starch, \% & 32.3 & 29.7 & 32.4 & 29.7 \\
\hline Long-chain fatty acids, \% & 2.3 & 2.7 & 2.4 & 2.8 \\
\hline Ash, \% & 6.1 & 6.1 & 6.0 & 6.0 \\
\hline $\mathrm{Ca}, \%$ & 1.00 & 1.05 & 0.97 & 1.01 \\
\hline $\mathrm{P}, \%$ & 0.39 & 0.42 & 0.39 & 0.42 \\
\hline $\mathrm{K}, \%$ & 1.03 & 1.09 & 1.05 & 1.11 \\
\hline $\mathrm{Mg}, \%$ & 0.20 & 0.21 & 0.18 & 0.19 \\
\hline $\mathrm{Na}, \%$ & 0.40 & 0.38 & 0.40 & 0.38 \\
\hline
\end{tabular}

${ }^{1}$ All diets contained $55 \%$ corn silage made from a dual-purpose (DP) or brown midrib (BMR) hybrid and were formulated to supply 85 or $115 \%$ of estimated (NRC, 2001) MP requirements.

${ }^{2}$ Values for $\mathrm{NE}_{\mathrm{L}}, \mathrm{RDP}$, and RUP concentrations and MP supply were calculated using measured nutrient composition and DMI and the NRC (2001) model. Nitrogen kinetic data from the NRC library were used.

\section{Manure Output and Digestibility}

No interactions $(P>0.15)$ were observed between hybrid and MP; therefore, only main effects will be discussed (Table 4). Intake during the 4-d collection period was higher for cows $(P<0.02)$ fed the high MP treatments than for cows fed low MP but it was not affected by hybrid. Manure excretion (wet feces plus urine) averaged $71.3 \mathrm{~kg} / \mathrm{d}$. The amount of manure excreted tended to be reduced when BMR was fed $(P<$ $0.09)$, mostly because of reduced excretion of fecal water $(P<0.07)$. Increasing milk production (negatively), DMI (positively), and DM concentration of the diet (negatively) have been shown to influence excretion of fecal water (Holter and Urban, 1992). Intake and diet DM concentration were not different between cows fed the different hybrids, but milk yield was higher $(P<$ 0.03) for cows fed BMR. However, using the equation derived by Holter and Urban (1992), the difference in milk yields between hybrid treatments would account for less than $10 \%$ of the observed difference in fecal water output. Feces from cows fed BMR were drier $(P$ $<0.03)$ than those from cows fed DP. Ireland-Perry and Stallings (1993) reported that dietary concentration of NDF was negatively correlated and concentration of dietary starch was positively correlated with fecal DM concentration, but neither of those 2 variables differed between hybrid treatments in this experiment. Excretion of fecal DM and water were not affected by MP, but fecal DM concentration was increased as MP increased. This effect may have been caused more by source of CP rather than concentration (Ireland-Perry and Stallings, 1993). Total manure output tended to increase with increasing MP.

Excretion of urine was about $25 \%$ greater $(P<0.01)$ for cows with high MP supply compared with those

Table 4. Effects of corn silage hybrid and MP supply on manure output and nutrient digestibility ${ }^{1}$

\begin{tabular}{|c|c|c|c|c|c|c|c|c|}
\hline & \multicolumn{2}{|c|}{ BMR } & \multicolumn{2}{|c|}{ DP } & \multirow[b]{2}{*}{ SEM } & \multicolumn{3}{|c|}{$P<{ }^{2}$} \\
\hline & Low & High & Low & High & & $\mathrm{H}$ & MP & $\mathrm{H} \times \mathrm{MP}$ \\
\hline $\mathrm{DMI}^{3}, \mathrm{~kg} / \mathrm{d}$ & 23.9 & 24.6 & 23.8 & 24.9 & 0.9 & - & 0.02 & - \\
\hline Wet feces, kg/d & 52.2 & 51.2 & 56.4 & 54.9 & 3.0 & 0.07 & - & - \\
\hline Dry feces, $\mathrm{kg} / \mathrm{d}$ & 8.3 & 8.4 & 8.5 & 8.6 & 0.4 & - & - & - \\
\hline Fecal water, $\mathrm{kg} / \mathrm{d}$ & 44.0 & 42.8 & 47.9 & 46.2 & 12.8 & 0.07 & - & - \\
\hline Fecal DM, \% & 15.9 & 16.5 & 15.2 & 15.7 & 0.3 & 0.02 & 0.05 & - \\
\hline Urine, $\mathrm{kg} / \mathrm{d}$ & 16.2 & 20.1 & 15.4 & 19.0 & 1.9 & - & 0.01 & - \\
\hline Wet manure, $\mathrm{kg} / \mathrm{d}$ & 68.3 & 71.4 & 71.7 & 74.0 & 3.1 & 0.09 & 0.13 & - \\
\hline \multicolumn{9}{|c|}{ Digestibility coefficients, $\%$} \\
\hline DM & 65.5 & 65.7 & 64.4 & 65.3 & 0.7 & - & - & - \\
\hline $\mathrm{OM}$ & 66.6 & 67.0 & 65.7 & 66.5 & 0.7 & - & - & - \\
\hline Energy & 64.8 & 65.0 & 62.8 & 64.6 & 1.0 & 0.15 & - & - \\
\hline NDF & 50.6 & 53.8 & 50.8 & 51.7 & 1.7 & - & 0.18 & - \\
\hline Starch & 83.1 & 82.4 & 85.0 & 83.3 & 1.9 & - & - & - \\
\hline $\mathrm{N}$ & 64.2 & 65.5 & 60.9 & 66.2 & 1.6 & - & 0.04 & 0.19 \\
\hline $\mathrm{DE},{ }^{4} \mathrm{Mcal} / \mathrm{kg}$ & 2.71 & 2.75 & 2.64 & 2.75 & 0.04 & - & 0.05 & - \\
\hline DE intake, Mcal/d & 64.8 & 67.5 & 62.9 & 68.6 & 2.6 & - & 0.01 & - \\
\hline
\end{tabular}

${ }^{1}$ Diets contained corn silage from a brown midrib (BMR) or dual-purpose (DP) hybrid and supplied 85 (Low) or 115\% (High) of estimated (NRC, 2001) MP.

${ }^{2} P$-values for main effects of hybrid $(\mathrm{H})$, MP, and the interaction between $\mathrm{H}$ and $\mathrm{MP}(\mathrm{H} \times \mathrm{MP}) . P$-values greater than 0.20 are not shown.

${ }^{3} \mathrm{DMI}$ is for the $4 \mathrm{~d}$ that cows were in metabolism stalls.

${ }^{4} \mathrm{DE}=$ Digestible energy. 
with low MP (Table 4). Intake of $\mathrm{K}$ was slightly higher (approximately $10 \mathrm{~g} / \mathrm{d}$ ) for cows fed high CP diets, which might have increased urine output slightly (Bannink et al., 1999). The difference in CP intake between cows fed the high and low MP treatments likely accounted for most of the difference in urine output (Holter and Urban, 1992; Wattiaux and Karg, 2004). Cows (similar DMI and milk production as in our study) excreted 28\% more urine when fed a corn silage-based diet with $17.1 \%$ CP compared with those fed a $16.2 \%$ CP diet (Wattiaux and Karg, 2004). Urine output by cows in that study, however, averaged 26.5 $\mathrm{L} / \mathrm{d}$ (50\% greater than the average in this study). Potassium intake by cows in the Wattiaux and Karg study likely (data not presented) was higher because their diets contained about $14 \%$ alfalfa. They also used indwelling catheters to collect urine, whereas we used externally attached urine cups. Urine output by gilts was almost twice as great and urinary $\mathrm{N}$ excretion was $20 \%$ greater when urine was collected via an indwelling catheter compared with an externally attached tube (Patience et al., 1987). The effect of method of urine collection on excretion of urine and urine $\mathrm{N}$ in cows needs to be determined to ensure artifacts are not being introduced because of research methodology.

Total water excretion was estimated by assuming the water concentration in urine and milk was 95 and $87 \%$, respectively and adding those values to fecal water. Mean excretion of water was $91.6,94.7,93.4$, and $96.7 \mathrm{~kg} / \mathrm{d}(\mathrm{SEM}=3.0)$ for cows fed BMR silage with low and high $\mathrm{CP}$ and cows fed DP silage with low and high $\mathrm{CP}$, respectively. Increased $\mathrm{CP}$ concentration increased $(P<0.07)$ water excretion but hybrid had no effect. Water intake was not measured in this experiment, but because DM concentrations of the TMR were similar, water intake likely was increased when the high CP diets were fed.

Nutrient digestibility was not affected by treatment except for higher $(P<0.05)$ digestibility of $\mathrm{N}$ for cows fed the high CP diets (Table 4). This effect could have been caused by differences in supplemental CP sources between diets or by dilution of metabolic fecal N. Apparent digestibility of $\mathrm{N}$ usually increases as the concentration of dietary CP increases (Preston, 1980). Direct comparisons of hybrid effects in this experiment with those in other experiments is difficult because hybrids (both the conventional and BMR) differed among experiments. Generally, nutrient digestibility of diets with BMR were similar to or slightly higher than for diets with conventional hybrids (Oba and Allen, 2000b; Greenfield et al., 2001; Tine et al., 2001; Ebling and Kung, 2004). In those experiments, cows fed BMR silage had higher DMI than cows fed diets with the conventional hybrid. The effects of DMI on digestibility (Tyrrell and Moe, 1975) could have reduced hybrid effects on digestibility. Hybrid did not affect DMI in our study. Tine et al. (2001) restricted DMI of cows fed diets with BMR silage to that of cows fed diets with an isogenic hybrid and reported a significant increase (10 percentage units) in NDF digestibility, a significant, but small (1.2 percentage units) increase in digestibility of DM, no effect on energy digestibility, and a significant (but small) decrease in digestibility of CP.

Digestibility of starch for all treatments was lower than average for dairy cattle (Firkins et al., 2001). Corn silage provided approximately $55 \%$ of the starch in the diet, and both silages contained 37\% DM (slightly drier than typically recommended). Digestibility of starch is reduced as the DM concentration of corn silage increases (Johnson et al., 1999).

\section{Nitrogen Metabolism}

As expected, MP supply had a major influence of $\mathrm{N}$ metabolism (Table 5). Cows fed the high CP diets consumed more total and digestible $\mathrm{N}$, excreted more $\mathrm{N}$ in feces and urine, and retained more $\mathrm{N}$ than cows fed the low CP diets $(P<0.03)$. Hybrid did not affect fecal or urinary excretion of $\mathrm{N}$, but cows fed diets with BMR secreted more $\mathrm{N}$ in milk $(P<0.04)$ than cows fed DP silage. Others have reported that feeding BMR silage reduced (Tine et al., 2001) or tended to reduce (Greenfield et al., 2001) urinary excretion of $\mathrm{N}$ by dairy cows.

The percentage of consumed $\mathrm{N}$ excreted in feces (34.1 vs. $37.4 \%)$ and secreted in milk (27.7 vs. 33.0 ) was lower $(P<0.04)$, and the percentage excreted in urine (31.5 vs. $28.0 \%)$ and retained (6.6 vs. $1.4 \%)$ tended to be $(P<0.10)$ or was higher $(P<0.01)$ for cows fed the high CP diets compared with low CP. Cows fed BMR silage tended $(P<0.10)$ to secrete a larger proportion of $\mathrm{N}$ intake into milk than cows fed DP silage (31.1 vs. $29.7 \%)$. No interactions $(P>0.20)$ between hybrid and MP were observed for any measure of $\mathrm{N}$ metabolism.

Excretion of urinary N (Table 5) and MUN concentrations (Table 6) were increased when cows were fed the high CP diets, and the 2 variables were correlated ( $\mathrm{r}=0.57 ; P<0.01)$. The concentration of MUN can be used to estimate excretion of urinary N (Kauffman and St-Pierre, 2001; Kohn et al., 2002). The best current equation (Kohn et al., 2002) is: Urinary N ( $\mathrm{g} / \mathrm{d})=\mathrm{MUN}$ $(\mathrm{mg} / \mathrm{dL}) \times 0.026 \times \mathrm{BW}(\mathrm{kg})$. The average MUN for the low and high CP treatments yielded estimated urinary $\mathrm{N}$ excretion values of 219 and $289 \mathrm{~g} / \mathrm{d}$, respectively. Both estimated values were approximately $65 \mathrm{~g} / \mathrm{d}$ greater than actual average $\mathrm{N}$ excretion, but the equa- 
Table 5. Effects of corn silage hybrid and MP supply on $\mathrm{N}$ metabolism ${ }^{1}$

\begin{tabular}{|c|c|c|c|c|c|c|c|}
\hline & \multicolumn{2}{|c|}{ BMR } & \multicolumn{2}{|c|}{ DP } & \multirow[b]{2}{*}{ SEM } & \multicolumn{2}{|c|}{$P<{ }^{2}$} \\
\hline & Low & High & Low & High & & $\mathrm{H}$ & $\mathrm{MP}$ \\
\hline \multicolumn{8}{|l|}{ Mass, g/d } \\
\hline $\mathrm{N}$ intake & 561 & 701 & 554 & 695 & 25 & - & 0.01 \\
\hline Fecal N & 202 & 241 & 219 & 235 & 15 & - & 0.03 \\
\hline Digested N & 361 & 457 & 338 & 458 & 16 & - & 0.01 \\
\hline Urinary $\mathrm{N}$ & 161 & 212 & 150 & 227 & 15 & - & 0.01 \\
\hline Manure N & 371 & 461 & 377 & 470 & 32 & - & 0.01 \\
\hline Milk N & 192 & 197 & 178 & 189 & 8 & 0.04 & 0.12 \\
\hline $\mathrm{N}$ retained & 10 & 51 & 8 & 41 & 17 & - & 0.01 \\
\hline Productive $\mathrm{N}^{3}$ & 201 & 249 & 185 & 230 & 22 & 0.04 & 0.01 \\
\hline \multicolumn{8}{|l|}{$\%$ of $\mathrm{N}$ intake } \\
\hline Fecal N & 35.8 & 34.5 & 39.1 & 33.8 & 1.6 & - & 0.04 \\
\hline Urinary N & 28.8 & 30.3 & 27.3 & 32.8 & 2.6 & - & 0.11 \\
\hline Manure N & 64.4 & 64.8 & 66.5 & 66.7 & 2.6 & 0.16 & - \\
\hline Milk N & 34.1 & 28.2 & 32.0 & 27.3 & 1.0 & 0.10 & 0.01 \\
\hline $\mathrm{N}$ retained & 1.5 & 7.2 & 1.4 & 6.0 & 2.6 & - & 0.01 \\
\hline Productive N & 35.6 & 35.2 & 33.5 & 33.3 & 2.7 & 0.16 & - \\
\hline
\end{tabular}

${ }^{1}$ Diets contained corn silage from a brown midrib (BMR) or dual-purpose (DP) hybrid and supplied 85 (Low) or $115 \%$ (High) of estimated (NRC, 2001) MP requirements.

${ }^{2} P$-values for main effects of hybrid $(\mathrm{H})$ and MP. No interactions between $\mathrm{H}$ and MP were observed $(P>$ $0.20)$. $P$-values greater than 0.20 are not shown.

${ }^{3}$ Productive $\mathrm{N}=$ milk $\mathrm{N}$ plus retained $\mathrm{N}$.

tion did estimate the difference between treatments reasonably well.

Because $\mathrm{N}$ intake had such a strong influence on $\mathrm{N}$ excretion, a statistical analysis was conducted using $\mathrm{N}$ intake as a continuous variable and hybrid as a fixed effect to determine more accurately the hybrid effects at a given $\mathrm{N}$ intake. No interactions were observed between $\mathrm{N}$ intake and hybrid. Intake of $\mathrm{N}$ had a significant positive effect $(P<0.01)$ on excretion of fecal, urinary, and total manure $\mathrm{N}$, secretion of milk $\mathrm{N}$, and $\mathrm{N}$ retention. Hybrid did not affect excretion of fecal or urinary $\mathrm{N}$ but did affect excretion of $\mathrm{N}$ in manure and milk. At a given $\mathrm{N}$ intake, cows fed BMR excreted 14.8 $( \pm 8) \mathrm{g} / \mathrm{d}$ less $(P<0.08)$ manure $\mathrm{N}$ and secreted 10.2 $( \pm 4.5) \mathrm{g} / \mathrm{d}$ more $(P<0.05)$ milk $\mathrm{N}$ than cows fed DP silage. The effect of hybrid on manure $\mathrm{N}$ excretion was quantitatively small compared with the effect of $\mathrm{N}$ intake. On average, feeding the low $\mathrm{CP}$ diets reduced manure $\mathrm{N}$ excretion by approximately $21 \%$ compared with feeding the high CP diets, whereas feeding diets with BMR silage reduced manure $\mathrm{N}$ excretion by $3.6 \%$. In other experiments in which DMI was similar between cows fed BMR and isogenic silage (Greenfield et al., 2001; Tine et al., 2001), excretion of $\mathrm{N}$ via ma-

Table 6. Effects of corn silage hybrid and MP supply on production measures ${ }^{1}$

\begin{tabular}{|c|c|c|c|c|c|c|c|c|}
\hline & \multicolumn{2}{|c|}{ BMR } & \multicolumn{2}{|c|}{ DP } & \multirow[b]{2}{*}{ SEM } & \multicolumn{3}{|c|}{$P<{ }^{2}$} \\
\hline & Low & High & Low & High & & $\mathrm{H}$ & MP & $\mathrm{H} \times \mathrm{MP}$ \\
\hline DMI, kg/d & 24.5 & 25.2 & 24.8 & 25.0 & 0.6 & - & 0.10 & - \\
\hline $\mathrm{BW}, \mathrm{kg}$ & 635 & 628 & 635 & 634 & 7 & - & 0.08 & 0.16 \\
\hline BW change, kg/d & -0.55 & 0.11 & -0.67 & -0.54 & 0.40 & 0.18 & 0.16 & - \\
\hline Milk, kg/d & 36.4 & 37.4 & 34.9 & 35.7 & 1.3 & 0.03 & - & - \\
\hline $\mathrm{ECM},{ }^{3} \mathrm{~kg} / \mathrm{d}$ & 36.8 & 38.2 & 37.3 & 38.7 & 1.4 & - & 0.16 & - \\
\hline ECM/DMI, kg/kg & 1.50 & 1.51 & 1.51 & 1.55 & 0.06 & - & - & - \\
\hline Milk fat, $\%$ & 3.64 & 3.71 & 4.04 & 4.17 & 0.31 & 0.01 & - & - \\
\hline Milk protein, \% & 3.08 & 3.14 & 3.13 & 3.13 & 0.09 & - & - & - \\
\hline MUN, mg/dL & 13.0 & 17.7 & 13.5 & 17.6 & 0.59 & - & 0.01 & - \\
\hline Milk fat, kg/d & 1.32 & 1.39 & 1.46 & 1.49 & 0.10 & 0.07 & - & - \\
\hline Milk protein, $\mathrm{kg} / \mathrm{d}$ & 1.13 & 1.19 & 1.14 & 1.12 & 0.04 & 0.16 & - & 0.08 \\
\hline
\end{tabular}

${ }^{1}$ Diets contained corn silage from a brown midrib (BMR) or dual-purpose (DP) hybrid and supplied 85 (Low) or $115 \%$ (High) of estimated (NRC, 2001) MP requirements.

${ }^{2} P$-values for main effects of hybrid $(\mathrm{H})$, MP, and the interaction between $\mathrm{H}$ and $\mathrm{MP}(\mathrm{H} \times \mathrm{MP}) . P$-values greater than 0.20 are not shown.

${ }^{3}$ Energy-corrected milk (Tyrrell and Reid, 1965). 
Table 7. Effects of corn silage hybrid and MP supply on ruminal measures ${ }^{1}$

\begin{tabular}{|c|c|c|c|c|c|c|c|}
\hline & \multicolumn{2}{|c|}{ BMR } & \multicolumn{2}{|c|}{$\mathrm{DP}$} & \multirow[b]{2}{*}{ SEM } & \multicolumn{2}{|c|}{$P<{ }^{2}$} \\
\hline & Low & High & Low & High & & $\mathrm{H}$ & MP \\
\hline $\mathrm{NH}_{3}, \mathrm{~m} M$ & 5.46 & 5.65 & 6.36 & 6.28 & 0.54 & 0.15 & - \\
\hline Total VFA, mM & 107.4 & 109.3 & 108.1 & 104.2 & 7.9 & - & - \\
\hline $\mathrm{pH}$ & 5.87 & 5.92 & 5.86 & 5.98 & 0.067 & - & 0.14 \\
\hline Molar proportions, mol/100 mol of total VFA & & & & & & & \\
\hline Acetate & 59.5 & 61.5 & 59.8 & 59.7 & 2.0 & - & - \\
\hline Propionate & 23.1 & 19.3 & 22.1 & 21.1 & 2.4 & - & 0.18 \\
\hline Butyrate & 12.6 & 14.1 & 12.9 & 13.4 & 1.1 & - & 0.07 \\
\hline Isobutyrate & 0.5 & 0.7 & 0.7 & 0.8 & 0.08 & - & 0.06 \\
\hline Valerate & 2.4 & 2.0 & 2.3 & 2.7 & 0.28 & - & - \\
\hline Isovalerate & 1.8 & 2.3 & 2.4 & 2.5 & 0.31 & - & - \\
\hline
\end{tabular}

\footnotetext{
${ }^{1}$ Diets contained corn silage from a brown midrib (BMR) or dual-purpose (DP) hybrid and supplied 85 (Low) or $115 \%$ (High) of estimated (NRC, 2001) MP requirements. Values shown are averaged over time $(0,3,6,9$, and $12 \mathrm{~h}$ postfeeding).

${ }^{2} P$-values for main effects of hybrid $(\mathrm{H})$ and MP. No interactions between $\mathrm{H}$ and MP were observed $(P>$ $0.20)$. $P$-values greater than 0.20 are not shown. Time postfeeding affected all values $(P<0.05)$, but except for acetate $(P<0.05)$, no time by main effect interactions were observed $(P>0.20)$.
}

nure was reduced between 3.3 and $7.8 \%$ when BMR silage was fed. Feeding BMR silage rather than DP silage would have the same effect on manure $\mathrm{N}$ excretion as would feeding approximately $22 \mathrm{~g} / \mathrm{d}$ less $\mathrm{N}$.

\section{Ruminal Measures}

Time postfeeding affected all ruminal measures shown in Table 7 . With the exception of a time $\times$ MP interaction for molar proportion of acetate $(P<0.05)$, no time $\times$ diet main effects were observed (data not shown). No interactions between hybrid and MP were observed $(P>0.20)$. Cows with high MP supply tended to have increased molar proportions of butyrate $(P<$ $0.07)$ and isobutyrate $(P<0.06)$, but no other diet main effects were observed. Hybrid did not affect ruminal $\mathrm{pH}$ or concentrations of VFA. The lack of a hybrid effect on VFA concentrations is consistent with previous studies (Oba and Allen, 2000a; Greenfield et al., 2001), but cows fed BMR silage in those 2 studies had lower mean ruminal $\mathrm{pH}$ than did cows fed the conventional hybrid. Ruminal $\mathrm{pH}$ was not affected by hybrid in this study. Different BMR and conventional hybrids were used in this experiment (hybrids were the same in the 2 previously cited studies). Also, DMI increased when BMR was fed in those 2 studies but not in the current experiment. The increased intake could have reduced ruminal $\mathrm{pH}$ by increasing supply of fermentable substrate in the rumen.

Even though cows on the low MP treatments consumed an average of $125 \mathrm{~g} / \mathrm{d}$ less $\mathrm{N}$ than those on the high MP treatments, average ruminal ammonia concentrations were not affected by treatment (Table 7 and Figure 1). Ruminal ammonia concentrations are dependent on supply of RDP and on rate of bacterial growth. All diets were formulated to contain the same concentration of RDP and to provide slightly more RDP than required. Supply of RDP averaged $101 \%$ of RDP requirement (range was 100.2 to $102 \%$ ) as calculated using NRC (2001). Assuming ruminal digestibility of $\mathrm{OM}$ of the diets was similar, the lack of an MP effect on rumen ammonia agrees with the calculated equal intakes of RDP. Oba and Allen (2000b) reported that rumen ammonia concentrations were reduced $(P<$ 0.09 ) when BMR silage was fed, which they attributed to increased bacterial protein synthesis. A similar, albeit weak $(P<0.15)$, trend was observed in this study.

\section{Production Measures}

Dry matter intake tended to be higher $(P<0.10)$ for cows fed high MP diets than for cows fed low CP diets (Table 6). From a review of literature, Roffler et al. (1986) determined that increasing dietary CP from about 14 to $17 \%$ with solvent-extracted soybean meal in corn silage-based diets resulted in an average increase in DMI of about $0.4 \mathrm{~kg} / \mathrm{d}$. Dietary CP was increased from 14.3 to $17.1 \%$ in our study by the addition of fish meal and lignosulfonated soybean meal, but the response in DMI was very similar to that obtained by Roffler et al. (1986). Cabrita et al. (2003), however, reported that increasing CP from 14 to $15.7 \%$ increased DMI by $2 \mathrm{~kg} / \mathrm{d}$ (10\%) when dairy cows were fed corn silage-based diets. The low $\mathrm{CP}$ diet in that study was formulated to be deficient in RDP. Using diet ingredient data and DMI published by Cabrita et al. (2003), RDP supply from the $14 \%$ and $15.7 \% \mathrm{CP}$ diets was about $7 \%$ less and $16 \%$ greater than requirement, respectively, as calculated by the NRC (2001) model. 


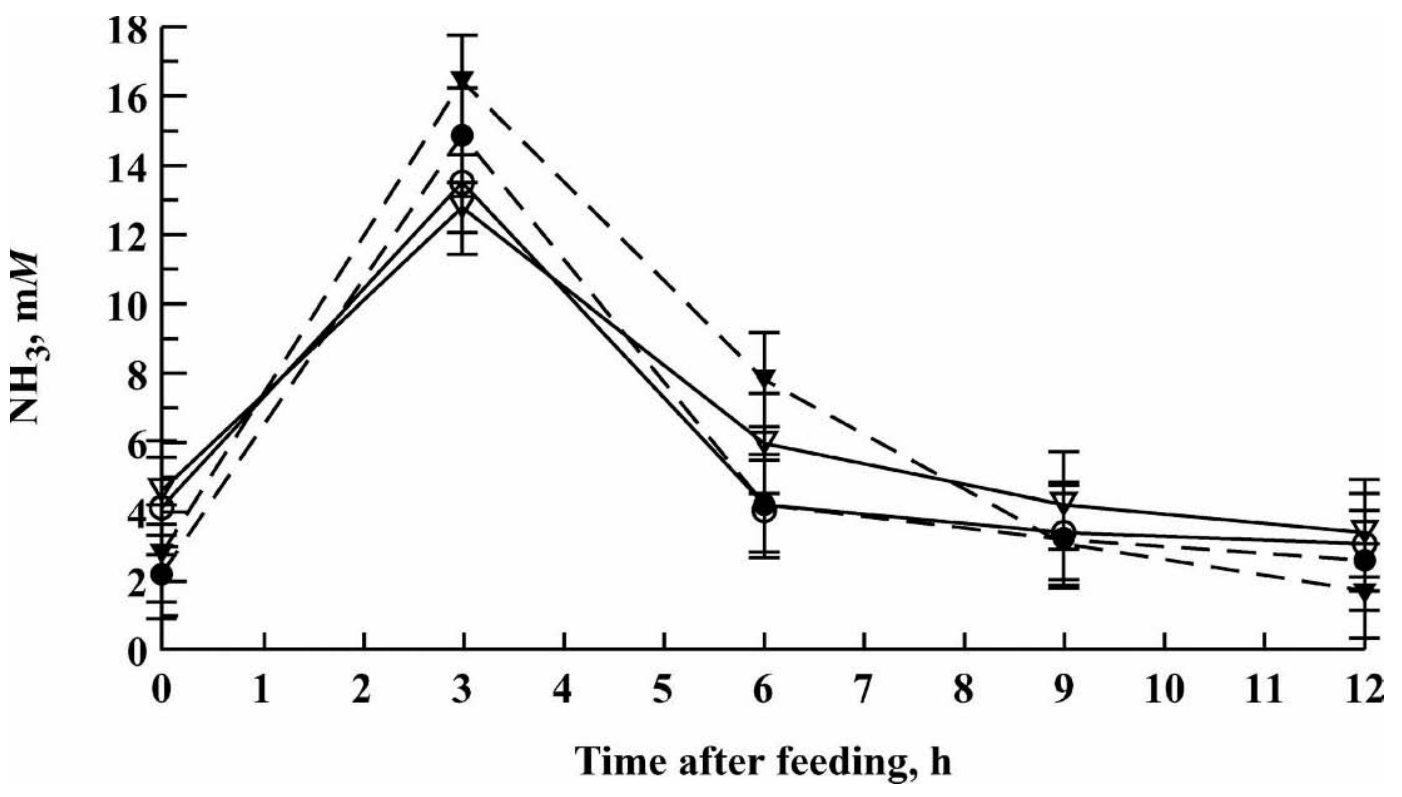

Figure 1. Ruminal ammonia concentrations in cows fed corn silage from a brown midrib hybrid (circles) or a dual-purpose hybrid (triangles) in diets formulated to provide 85 (filled symbols and dashed lines) or 115\% of NRC (2001) MP requirements (open symbols and solid lines).

Most previous studies (Oba and Allen, 1999, 2000a; Greenfield et al., 2001; Tine et al., 2001; Qiu et al., 2003; Ebling and Kung, 2004) reported increased DMI when cows were fed BMR corn silage; however, DMI was not affected by hybrid in this study. The lack of response may have been caused by hybrid differences. With the exception of Ebling and Kung (2004), all those studies compared a BMR hybrid with a hybrid that was isogenic to the BMR hybrid with the exception of the bm3 mutation. In our study, the control hybrid was not isogenic to the BMR hybrid, but nutrient composition of the 2 silages was very similar except for lignin concentrations. The difference in IVNDFD between the DP and BMR hybrids in this study was similar to that observed between BMR and its isogenic hybrid (Oba and Allen, 1999, 2000a). Another difference between our study and previous experiments that may have affected DMI response is dietary protein. All the previous studies used diets that contained $\geq 17 \% \mathrm{CP}$ and, based on ingredient composition of the diets, probably had higher concentrations of RDP than the diets in the present experiment. Diets based on corn silage that are deficient in RDP can reduce DMI (Cabrita et al., 2003), and the diets fed in this experiment may have been limiting in RDP.

Protein had no effect on milk production, milk fat, or milk protein (Table 6). Based on the NRC (2001), MP allowable milk was approximately $32 \mathrm{~kg} / \mathrm{d}$ for the low $\mathrm{CP}$ diets and $45 \mathrm{~kg} / \mathrm{d}$ for the high CP diets. Actual milk production averaged $36 \mathrm{~kg} / \mathrm{d}$, which means that the NRC model underestimated MP supply, overestimated MP requirements, or did both for the low MP treatments. The high CP diets greatly increased MUN $(P<0.01)$. The concentration of dietary $\mathrm{CP}$ has a strong positive correlation with MUN (Broderick and Clayton, 1997) and can be affected by the proportion of RDP and RUP in the CP. In our experiment, diets were formulated to contain equal concentrations of RDP, and the difference in $\mathrm{CP}$ was caused by the addition of RUP. Ruminal ammonia data (Table 7) support the premise of similar RDP concentrations among diets. Therefore, the increase in MUN was likely caused by catabolism of amino acids within the cow rather than absorption of ammonia from the rumen.

Cows fed BMR produced more milk $(P<0.03)$ than cows fed DP silage but, because concentration and yield of fat was lower $(P<0.01$ and $P<0.07$, respectively) for cows fed BMR, the yield of ECM was not affected by hybrid. Yields of milk and fat-corrected or energy-corrected milk are usually (Oba and Allen, 1999, 2000a; Ballard et al., 2001; Tine et al., 2001; Ebling and Kung, 2004), but not always (Greenfield et al., 2001; Qiu et al., 2003), higher for cows fed BMR corn silage than conventional corn silage. In most of the above-cited studies, yield of milk fat was not affected by corn silage hybrid, but milk fat percentage was reduced when BMR silage was fed in some studies (Oba and Allen, 2000a; Qiu et al., 2003). Oba and Allen (2000a) observed an interaction between the concentration of dietary NDF and hybrid for milk fat percent- 
age. Milk fat was reduced when BMR silage was included in diets with $28 \%$ NDF but was not affected when diets contained $38 \%$ NDF. The diets in our study contained approximately $32 \% \mathrm{NDF}$, which should have been adequate (NRC, 2001). The decrease in milk fat yield and concentration are in contrast to the lack of effects of hybrid on ruminal measures (Table 7). Increased milk yield by cows fed BMR could partially explain the reduced milk fat percentage but not the reduced milk fat yield. An interaction was observed between MP and hybrid for milk protein yield. Cows fed the BMR with high protein produced more milk protein than other treatments. Intake of DE (Table 5) did not follow the same pattern as did milk protein yield, therefore energy intake was likely not the reason for increased milk protein on the BMR plus high protein diet. Milk protein yields can be increased by altering the duodenal supply of different amino acids (NRC, 2001). We have no data on duodenal flow of amino acids from this experiment, but duodenal flow of amino acids and their proportions (\% of MP) were probably altered by protein treatment and may have been affected by hybrid treatment. Microbial protein flow from the rumen was higher in cows fed BMR silage than in cows fed isogenic silage in one study (Oba and Allen, 2000b), but not in another (Greenfield et al., 2001). If microbial protein synthesis was increased by feeding BMR silage, the combination of increased RUP and microbial protein may have altered the flow of amino acids to the duodenum, thereby increasing milk protein yield by cows fed the BMR plus high protein diet. Additional research is needed to evaluate that hypothesis.

\section{CONCLUSIONS}

Excretion of manure was increased by feeding diets with increased concentrations of $\mathrm{CP}$ and tended to be reduced when BMR silage was fed, but digestibility of nutrients were mostly unaffected by diet. Excretion of $\mathrm{N}$ in manure was $24 \%$ higher when cows were fed diets with $17.5 \% \mathrm{CP}$ compared with those fed diets with $14.0 \%$ CP. At equal $\mathrm{N}$ intakes, feeding BMR silage reduced $\mathrm{N}$ excretion by about $4 \%$. Yields of milk and milk components were not affected by MP supply suggesting that the all diets provided adequate MP even though the low CP diets supplied inadequate MP according to the NRC (2001) model. Diets with BMR increased yield of milk but reduced yield of milk fat. Feeding high MP with BMR resulted in an increase in milk protein yield, suggesting that hybrid may affect protein supplementation strategies.

\section{ACKNOWLEDGMENTS}

We thank Kevin Miller and Raymond Windsor for managing and caring for the cows used in this study, Tonya McKelvey for performing laboratory analyses, and Dow AgroSciences, LLC (Indianapolis, IN) for providing financial assistance.

\section{REFERENCES}

Ankom Technology. 2003. Method for determining neutral detergent fiber (aNDF). Ankom Technology, Macedon, NY.

AOAC. 2000. Official Methods of Analysis. Vol. 1 and 2. 17th ed. AOAC International, Gaithersburg, MD.

Ballard, C. S., E. D. Thomas, D. S. Tsang, P. Mandebvu, C. J. Sniffen, M. I. Endres, and M. P. Carter. 2001. Effect of corn silage hybrid on dry matter yield, nutrient composition, in vitro digestion, intake by dairy heifers, and milk production by dairy cows. J. Dairy Sci. 84:442-452.

Bannink, A., H. Valk, and A. M. VanVuuren. 1999. Intake and excretion of sodium, potassium, and nitrogen and the effects on urine production by lactating dairy cows. J. Dairy Sci. 82:1008-1018.

Broderick, G. A., and M. K. Clayton. 1997. A statistical evaluation of animal and nutritional factors influencing concentrations of milk urea nitrogen. J. Dairy Sci. 80:2964-2971.

Cabrita, A. R. J., A. J. M. Fonseca, R. J. Dewhurst, C. V. P. Sampaio, M. F. S. Miranda, G. N. S. Sousa, I. M. F. Miranda, and E. Gomes. 2003. Nitrogen supplementation of corn silages. 1. Effects on feed intake and milk production of dairy cows. J. Dairy Sci. 86:4008-4019.

Ebling, T. L., and L. Kung. 2004. A comparison of processed conventional corn silage to unprocessed and processed brown midrib corn silage on intake, digestion, and milk production by dairy cows. J. Dairy Sci. 87:2519-2526.

Environmental Protection Agency. 2003. National pollutant discharge elimination system permit regulation and effluent limitation guidelines and standards for concentrated animal feeding operations (CAFOs): Final Rule. Fed. Regist. 68 (No. 29) 71757274 (Feb. 12)

Firkins, J. L., M. L. Eastridge, N. R. St-Pierre, and S. M. Noftsger. 2001. Effects of grain variability and processing on starch utilization by lactating dairy cows. J. Anim. Sci. 79(E. Suppl.):E218-E238.

Greenfield, T. L., R. L. Baldwin, R. A. Erdman, and K. R. McLeod. 2001. Ruminal fermentation and intestinal flow of nutrients by lactating cows consuming brown midrib corn silages. J. Dairy Sci. 84:2469-2477.

Holter, J. B., and J. W. E. Urban. 1992. Water partitioning and intake prediction in dry and lactating Holstein cows. J. Dairy Sci. 75:1472-1479.

Ireland-Perry, R. L., and C. C. Stallings. 1993. Fecal consistency as related to dietary composition in lactating Holstein cows. J. Dairy Sci. 76:1074-1082.

Johnson, L., J. H. Harrison, C. Hunt, K. Shinners, C. G. Doggett, and D. Sapienza. 1999. Nutritive value of corn silage as affected by maturity and mechanical processing: A contemporary review. J. Dairy Sci. 82:2813-2825.

Jonker, J. S., R. A. Kohn, and J. High. 2002. Dairy herd management practices that impact nitrogen utilization efficiency. J. Dairy Sci. 85:1218-1226.

Kauffman, A. J., and N. R. St-Pierre. 2001. The relationship of milk urea nitrogen to urine nitrogen excretion in Holstein and Jersey cows. J. Dairy Sci. 84:2284-2294.

Kohn, R. A., K. F. Kalscheur, and E. Russek-Cohen. 2002. Evaluation of models to estimate urinary nitrogen and expected milk urea nitrogen. J. Dairy Sci. 85:227-233.

National Research Council. 2001. Nutrient Requirements of Dairy Cattle. 7th rev. ed. ed. Natl. Acad. Press, Washington, DC. 
Oba, M., and M. S. Allen. 1999. Effects of brown midrib 3 mutation in corn silage on dry matter intake and productivity of high yielding dairy cows. J. Dairy Sci. 82:135-142.

Oba, M., and M. S. Allen. 2000a. Effects of brown midrib 3 mutation in corn silage on productivity of dairy cows fed two concentrations of dietary neutral detergent fiber: 1 . Feeding behavior and nutrient utilization. J. Dairy Sci. 83:1333-1341.

Oba, M., and M. S. Allen. 2000b. Effects of brown midrib 3 mutation in corn silage on productivity of dairy cows fed two concentrations of dietary neutral detergent fiber: 3 . Digestibility and microbial efficiency. J. Dairy Sci. 83:1350-1358.

Patience, J. F., M. S. Wolynetz, D. W. Friend, and K. E. Hartin. 1987. A comparison of two urine collection methods for female swine. Can. J. Anim. Sci. 67:859-863.

Preston, R. L. 1980. Empirical value of crude protein. Pages 201217 in Protein requirements for cattle. Vol. MP-109. F. N. Owens, ed. Oklahoma State Univ., Stillwater.

Qiu, X., M. L. Eastridge, and Z. Wang. 2003. Effects of corn silage hybrid and dietary concentration of forage NDF on digestibility and performance by dairy cows. J. Dairy Sci. 86:3667-3674.

Roffler, R. E., J. E. Wray, and L. D. Satter. 1986. Production responses in early lactation to additions of soybean meal to diets containing predominantly corn silage. J. Dairy Sci. 69:10551062.

Supelco. 1975. GC separation of VFA C2-C5, Bulletin 749D, Supelco, Inc., Bellefonte, PA.

SAS Institute. 1999. SAS/STAT User's Guide. Version 8. SAS Institute Inc., Cary, NC.

Spears, R. A., R. A. Kohn, and A. J. Young. 2003. Whole-farm nitrogen balance on western dairy farms. J. Dairy Sci. 86:4178-4186.

St-Pierre, N. R., and C. S. Thraen. 1999. Animal grouping strategies, sources of variation, and economic factors affecting nutrient balance on dairy farms. J. Anim. Sci. 77(Suppl. 2):72-83.

Tine, M. A., K. R. McLeod, R. A. Erdman, and R. L. Baldwin, VI. 2001. Effects of brown midrib corn silage on the energy balance of dairy cattle. J. Dairy Sci. 84:885-895.

Tyrrell, H. F., and P. W. Moe. 1975. Effect of intake on digestive efficiency. J. Dairy Sci. 58:1151-1163.

Tyrrell, H. F., and J. T. Reid. 1965. Prediction of the energy value of cow's milk. J. Dairy Sci. 48:1215-1223.

Wattiaux, M. A., and K. L. Karg. 2004. Protein level for alfalfa and corn silage-based diets: II. Nitrogen balance and manure characteristics. J. Dairy Sci. 87:3492-3502.

Weiss, W. P., and D. J. Wyatt. 2000. Effect of oil content and kernel processing of corn silage on digestibility and milk production by dairy cows. J. Dairy Sci. 83:351-358. 